\title{
FACTORS INFLUENCING MILLENNIALS PURCHASE INTENTION
}

\author{
Gina Fitriana ${ }^{1}$, Robert Kristaung ${ }^{2 *}$ \\ Faculty of Economics and Business, Trisakti University, Indonesia. \\ *Corresponding Author: robertkristaung@gmail.com
}

\begin{tabular}{l} 
ARTICLE INFO \\
\hline Article History: \\
Received: February 19, 2020 \\
Revised: July 09, 2020 \\
Published Online: August 17, 2020 \\
Keywords: \\
Deal Proneness, Attitude, Reciprocity, \\
Subjective Norms, Purchase Intention, \\
Millennials.
\end{tabular}

\section{How to cite:}

Fitriana, G., Kristaung, R. (2020). Factors Influencing Millennials Purchase Intention. International Journal of Digital Entrepreneurship and Business (IDEB), 1(1), $37-44$.

\begin{abstract}
This study examines the effect of attitude, subjective norms, deal proneness and reciprocity toward purchase intention through subjective norms. The purposive sampling method was used to obtain data from 190 consumers of Starbucks through Line social media and the company's official account and analyzed using the Structural Equation Modelling (SEM) and the Analysis of Moment Structure (AMOS) program. The result showed that (1) deal proneness positively influence attitude, (2) attitude has a positive influence on purchase intention, (3) reciprocity positively influence subjective norms, (4) subjective norms has a positive influence on purchase intention, (5) deal proneness positively influence purchase intention through attitude, and (6) reciprocity has a positive influence on purchase intention through subjective norms.
\end{abstract}

\section{INTRODUCTION}

Over the years, consumers have become more selective in choosing products suitable for their life needs. Therefore, companies need to create more effective and efficient marketing strategies to gain market share and high sales volume. Ryu and Feick (2007) stated that offering incentive to consumers by engaging them in word-of-mouth activities is a common marketing strategy used by companies. They can take advantage of this incentive to generate purchases by giving out coupons through social media.

Advanced communication and information technology have triggered the development of mobile commerce and marketing, thereby, leading to the widespread and use of mobile coupons (m-coupons) which contains messages that include texts, images, audios, and videos. Consumers can get these $\mathrm{m}-$ coupons through the company's website, application, social media, or friends and then receive discounts or cashback by showing it to the retailer (Dickinger \& Kleijnen, 2008).

Ma et al. (2015) stated that more than two-thirds of companies use social media to market their goods and services. It has become the media option worldwide with the ability to influence consumer behavior and perceptions. Mukerjee and Prasad (2017) stated that social media provides accurate information for consumers to make comparisons before making a purchase.

Starbucks is one of the most recognized food and beverage companies in Indonesia that applies technology and communications advancements to conduct sales promotions using M-coupon through social media. According to a 2012 publication by The Nielsen Company and the Asia-Pacific Campaign, the company is among the Asia's Top 1000 Brands and one of the 10 leading brands in Indonesia. Starbucks uses Twitter and Line social media for sales promotion. However, on Twitter, they only provide information that they give M-coupon through their Line official account, therefore, consumers are advised to add the company's official account to gain access to these coupon codes. 
Starbucks Indonesia's Line official account is ranked 1st in the category of food and beverage with $7,229,870$ adders in January 2018. Approximately $11 \%$ of their total adders always open promotional coupons offered, and $25 \%$ of them come to the booth for exchange. Deal proneness triggers a purchase intention through attitude. Therefore, a positive or negative attitude of a consumer towards promotional activities such as coupons encourages or discourages them from buying an item/service (Tercia \& Teichert, 2016).

The reciprocal relationship between consumers and companies depends on the subjective norms of the environment and this also triggers their purchase intentions through subjective norms. Reciprocity can be influenced by social, economic, and norms that triggers purchases (Tercia \& Teichert, 2016). Based on the aforementioned background description, this study focuses on how the positive effect of deal proneness and reciprocity influence consumers purchase Intention through attitude, and subjective norms.

\section{LITRATURE REVIEW}

Montaner et al. (2011) defined deal proneness as a general tendency for someone in responding to promotional activities in the form of an agreement. It enables consumers to view the deal as the ultimate goal with possibility of making a purchase (Price et al., 1988; Wirtz \& Chew, 2002). Consumers exhibit psychological patterns by positively responding to promotional offers derived from purchases on transactions. Therefore, deal proneness is a psychological tendency to purchase goods and services.

According to Sumida et al. (2014) attitude is a positive or negative evaluation of behavior and its expectations from consumers. Gouldner (1960) reported that reciprocity can be moral or instrumental. From a moral view, it has become a "general norm" and a moral code stating that it is the "right thing to do." Meanwhile, from an instrumental perspective, reciprocity is defined as a pattern of exchange of gratuities, where the recipient is expected to return good deeds to the giver in future, and vice versa. Reciprocity is a key concept in economics, sociology, sociobiology, political science, and anthropology (Li et al., 2013).

Subjective norms refer to social pressures felt by individuals to carry out certain behavior. It is related to an individual's belief that other people encourage or prevent them from engaging in certain behaviors. Therefore, people tend to carry out a behavior when motivated by others. Purchase intention is a desire or plan of consumers to buy a product by determining its quality.

Purchase intention is the process used to evaluate customer decision making (Lin \& Lin, 2007). According to Durianto and Liana (2004), purchase intention is related to the consumer's plan to purchase a particular brand, and the required number of units. It is part of the component of consumers' behavior act before making a purchase (Kinnear \& Taylor, 1995).

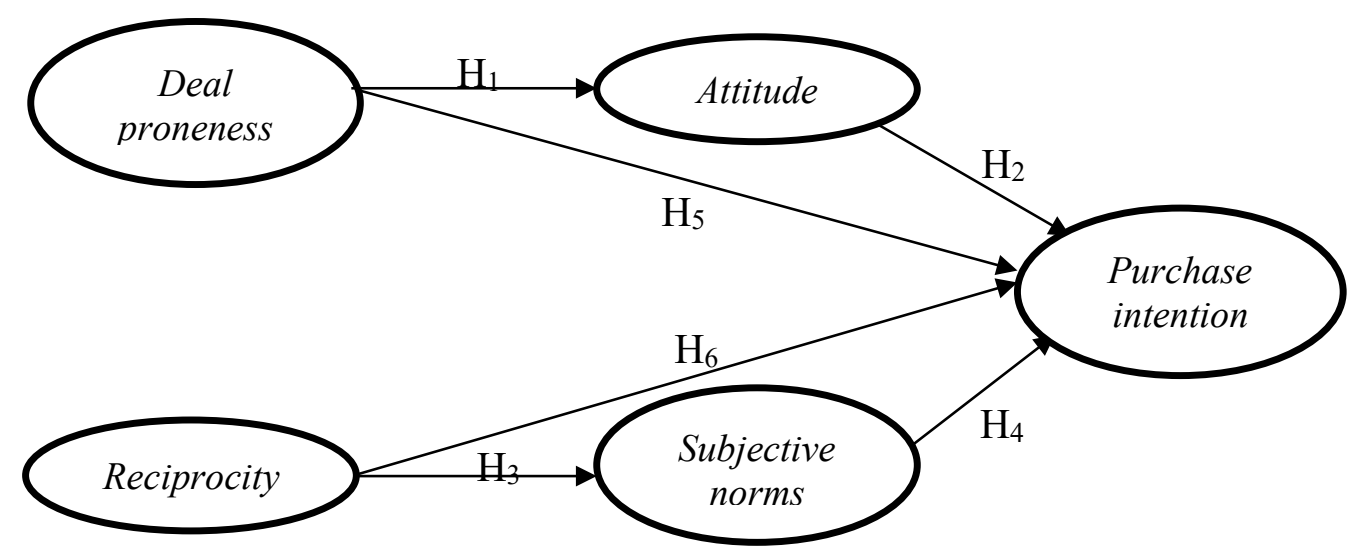

Figure 1: Conceptual Framework 
This study used five variables, namely deal proneness, attitude, reciprocity, subjective norms, and purchase intention. Deal proneness has been widely used in studies related to use of coupon (Tercia \& Teichert, 2016).

Previous studies verified deal proneness as generic consumer characteristics (Montaner et al., 2011). An empirical research carried out by Tercia and Teichert (2016) stated that it has a positive relationship towards promotional activities. According to Kacen and Lee (2002) deal proneness is associated with spontaneous consumer buying behavior based on pleasure and passion. Based on these descriptions, the following hypothesis was stated.

\section{$H_{1}$ : Deal proneness has a positive influence on attitude.}

Recipient's intention to redeem a coupon, attitude is more important when they are action-oriented, which indicates their high ability to perform an attitude. Previous studies have shown that positive attitudes lead to positive behavioral intentions in various cultural settings (Tercia \& Teichert, 2016). These studies expect attitudes to have a positive influence on consumers to redeem coupons received. Therefore, based on this description, the second hypothesis proposed in this study is as follows:

\section{$\mathrm{H}_{2}$ : Attitude has a positive effect on purchase intention.}

Tercia and Teichert (2016) reported that other social factors such as subjective norms, also encourages consumers to perform certain action. In this case, reciprocity which is related to equilibrium and justice is important because it enables them to make decisions and attitudes. This led to the formulation of the third hypothesis as follows:

\section{$H_{3}$ : Reciprocity has a positive influence on subjective norms.}

Besides attitude, someone's behavior is also dependent on subjective norms (Tercia \& Teichert, 2016). Therefore, recipients redeem coupons, when they have a low capacity to perform certain behaviors and need to rely on other's opinions (Kang et al. 2006). Based on this description, the fourth hypothesis was formulated as follows:

\section{$H_{4}$ : Subjective norms have a positive effect on purchase intention.}

Deal proneness consumers tend to use promotions or discounts spontaneously (Tercia \& Teichert, 2016). Therefore, it can be concluded that their existence is caused by impulsive purchases.

\section{$H_{5}$ : Deal proneness has a positive effect on purchase intention through attitude.}

Reciprocity tends to arise when the recipient has to return assistance or expect something in return from the giver. This most times encourages the coupon recipient to engage in purchasing activities (Tercia \& Teichert, 2016).

\section{$H_{6:}$ Reciprocity has a positive effect on purchase intentions through subjective norms.}

\section{METHOD}

To test the hypotheses and generally explain the characteristics of certain relationships or differences between groups (Hermawan \& Kristaung, 2014). The unit of analysis used is individual, such as consumers with Line accounts and have added the official Starbucks account with a coupon. The level of intervention in this study is minimum because data collection was carried out through questionnaires distributed directly to each respondent using cross-sectional data (Sekaran, 2010).

This study uses five variables: (1) deal proneness, (2) attitude, (3) reciprocity, (4) subjective norms, and (5) purchase intention. All variables are measured in the form of question and statement items using the interval scale type and Likert measurement techniques. Likert scale is designed to measure respondents' agreement or disagreement with objects related to statements on a 5 point scale, where $1=$ strongly disagree, 2 disagree, 3 = quite agree, $4=$ agree, and $5=$ strongly agree. Deal proneness, attitude, reciprocity, subjective norms, and purchase intention each have three statements adapted from the research carried out by Tercia and Teichert (2016), thereby, culminating in 15 questions or statements. 
Furthermore, this study used a non-probability sampling technique, and a subjective sampling procedure to select the population elements. The non-probability sampling technique used in this study is the purposive or judgmental method, which is based on certain criteria (Sekaran, 2010). This study was sourced from primary data obtained directly from the research object by distributing questionnaires. The unit of analysis is individuals, such as consumers that use Line social media and those that have added the official Starbucks accounts with re-deemed coupons. Besides, this research was carried out with data that was only collected once to answer the study questions.

Table 1: Respondents' Profile

\begin{tabular}{|l|r|r|}
\hline Gender & Frequency & Percentage \\
\hline Male & 67 & $35,3 \%$ \\
\hline Female & 123 & $64,7 \%$ \\
\hline Age & Frequency & Percentage \\
\hline$<20$ years old & 29 & $15,3 \%$ \\
\hline $20-25$ years old & 155 & $81,6 \%$ \\
\hline$>25$ years old & 6 & $3,2 \%$ \\
\hline Education & Frequency & Percentage \\
\hline High School & 145 & $76,3 \%$ \\
\hline Diploma & 20 & $10,5 \%$ \\
\hline Bachelor Degree & 24 & $12,6 \%$ \\
\hline Master Degree & 1 & $0,5 \%$ \\
\hline Occupation & Frequency & Percentage \\
\hline Civil Servants & 4 & $2,1 \%$ \\
\hline General employees & 21 & $11,1 \%$ \\
\hline entrepreneur & 8 & $4,2 \%$ \\
\hline Unemployed (Student/College student/ Housewife) & 157 & $82,6 \%$ \\
\hline Salary & Frequency & Percentage \\
\hline$<$ IDR 1.000.000 & 73 & $38,4 \%$ \\
\hline IDR 1.000.000-5.000.000 & 106 & $55,8 \%$ \\
\hline$>$ IDR 5.000.000 & 11 & $5,8 \%$ \\
\hline Social Media & 190 & $100 \%$ \\
\hline Use & 0 & $0 \%$ \\
\hline Don't Use & Frequency & Percentage \\
\hline Add Official Account & 190 & $100 \%$ \\
\hline Yes & 0 & $0 \%$ \\
\hline No & $\mathbf{1 9 0}$ & $\mathbf{1 0 0}$ \\
\hline Total & & \\
\hline Source: Quncy & Percentage \\
\hline
\end{tabular}

Source: Questionnaire data processed using SPSS.

A validity test was carried out using factor analysis with the loading factor analyzed using the SEM (Structural Equation Model) by AMOS software. Since the sample used is 190 respondents, then, The loading factor to be declared a valid instrument was assumed to be above 0.40 because the sample used is 190 consumers (Hair et al., 2010).

According to Sekaran and Bougie (2013) the reliability test is used to examine the consistency of the instrument in measuring each variable with a different concept. It was carried out to measure the respondents' consistency in answering each question. This test is measured by looking at the Cronbach's Alpha value of each variable, with decision-making criteria considered reliable assuming the value is above 0.6 (Hair et al., 2010). 
Table 2: Validity Test Result of Deal Proneness Variable

\begin{tabular}{|c|c|c|}
\hline Indicator of Deal Proneness Variables & $\begin{array}{c}\text { Loading } \\
\text { Factor }\end{array}$ & Decision \\
\hline I like to look for discount offers through Starbuck coupons. & 0,818 & Valid \\
\hline I felt happy when I redeemed the coupons. & 0,874 & Valid \\
\hline I bought Starbucks due to the coupon even though I do not need the product. & 0,729 & Valid \\
\hline \multicolumn{3}{|l|}{ Indicator of Attitude Variable } \\
\hline I find the coupons very useful & 0,890 & Valid \\
\hline I find the coupons very enjoyable & 0,917 & Valid \\
\hline I feel the coupons are very fair & 0,858 & Valid \\
\hline \multicolumn{3}{|l|}{ Indicator of Reciprocity Variable } \\
\hline $\begin{array}{l}\text { I hope Starbucks are satisfied when I redeem the coupons provided through } \\
\text { Line social media. }\end{array}$ & 0,861 & Valid \\
\hline $\begin{array}{l}\text { I redeemed Starbucks coupons in order to repay their kindness through Line } \\
\text { social media }\end{array}$ & 0,913 & Valid \\
\hline I redeemed the coupons because they always provide good service & 0,846 & Valid \\
\hline \multicolumn{3}{|l|}{ Indicator of Subjective Norms Variable } \\
\hline $\begin{array}{l}\text { The closest people around me argue that redeeming Starbucks coupons } \\
\text { provided through Line social media is a waste of time }\end{array}$ & 0,971 & Valid \\
\hline Those closest to me stated that it is worthy to redeem the coupons & 0,967 & Valid \\
\hline $\begin{array}{l}\text { Closest people around me stated that redeeming the coupons are very } \\
\text { beneficial. }\end{array}$ & 0,856 & Valid \\
\hline \multicolumn{3}{|l|}{ Indicator of Purchase Intention Variable } \\
\hline I tend to possibly redeem the coupons. & 0,850 & Valid \\
\hline I intend to redeem Starbucks coupons given through social media Line. & 0,919 & Valid \\
\hline I intend to redeem the coupons provided through Line social media soonest. & 0,873 & Valid \\
\hline
\end{tabular}

Source: Data processed using SPSS.

The data analysis method used in this research is Structural Equation Model (SEM) and AMOS software. SEM is a multivariate technique that combines aspects of multiple regression and factor analysis to estimate the series of relationships simultaneously (Hair et al., 2010). Before analyzing hypotheses, overall fit models need to be assessed in advance to ensure that the model has the ability to describe causal relationships.

Table 3: Reliability Test Results

\begin{tabular}{|l|c|c|}
\hline Variable & Cronbach Alpha & Decision \\
\hline Deal proneness & 0,705 & Reliable \\
\hline Attitude & 0,865 & Reliable \\
\hline Reciprocity & 0,843 & Reliable \\
\hline Subjective norms & 0,922 & Reliable \\
\hline Purchase intention & 0,856 & Reliable \\
\hline
\end{tabular}

Source: Data processed using SPSS.

Table 4: Goodness of Fit Model Test Results

\begin{tabular}{|c|c|c|}
\hline Goodness of Fit Index & Measurement results & Decision \\
\hline GFI & 0,867 & Goodness of Fit \\
\hline RMSEA & 0,099 & Goodness of Fit \\
\hline TLI & 0,909 & Goodness of Fit \\
\hline CFI & 0,928 & Goodness of Fit \\
\hline NFI & 0,894 & Goodness of Fit \\
\hline CMIN DF & 2,851 & Goodness of Fit \\
\hline
\end{tabular}

Source: Data processed using SPSS. 


\section{ANALYSIS AND DISCUSSION}

Descriptive statistical analysis of this study is as follows:

Table 5: Deal Proneness Descriptive Statistics

\begin{tabular}{|c|c|c|}
\hline Deal Proneness Indicator & Mean & St. Dev. \\
\hline I like to look for discount offers through coupons. & 4,132 & 0,9193 \\
\hline I feel happy when I redeemed the coupons offered. & 4,037 & 0,9222 \\
\hline I bought Starbucks due to coupon even though I do not need the product. & 3,389 & 1,2497 \\
\hline \multicolumn{3}{|l|}{ Attitude Indicator } \\
\hline I find the coupons very useful & 3,963 & 0,9670 \\
\hline The coupons are very enjoyable & 3,984 & 0,8697 \\
\hline The coupons are very fair & 3,895 & 0,9082 \\
\hline \multicolumn{3}{|l|}{ Reciprocity Indicator } \\
\hline $\begin{array}{l}\text { I hope Starbucks are grateful after I have redeemed the coupons provided } \\
\text { through Line social media. }\end{array}$ & 3,616 & 0,9621 \\
\hline I redeemed the coupons in a bid to repay their kindness & 3,595 & 0,9644 \\
\hline I redeemed the coupons because the company always provides good service & 3,695 & 1,0448 \\
\hline \multicolumn{3}{|l|}{$\begin{array}{l}\text { Subjective Norms Indicator } \\
\end{array}$} \\
\hline $\begin{array}{l}\text { The closest people around me argue that redeeming Starbucks coupons } \\
\text { provided through Line social media is a waste of time }\end{array}$ & 3,768 & 0,8539 \\
\hline Those closest to me stated that it is worthy to redeem the coupons. & 3,779 & 0,8443 \\
\hline $\begin{array}{l}\text { Closest people around me stated that redeeming the coupons are very } \\
\text { beneficial. }\end{array}$ & 3,853 & 0,8845 \\
\hline \multicolumn{3}{|l|}{ Purchase Intention Indicator } \\
\hline I tend to possibly redeem the coupons. & 3,684 & 0,9841 \\
\hline I intend to redeem Starbucks coupons given through social media Line. & 3,516 & 1,0922 \\
\hline I intend to redeem the coupons provided through Line social media soonest. & 3,353 & 1,0724 \\
\hline
\end{tabular}

Result analysis and interpretation carried out based on the hypotheses testing showed that the (Ho) was rejected while $(\mathrm{Ha})$ was accepted at an error tolerance limit $(\alpha)$ of $5 \%(0.05)$.

The first hypothesis examined the effect of deal proneness on attitude, which had a positive effect. It indicates that the deal proneness reflects a promotional tool in the form of a coupon that can affect consumers' attitude. The results of this study support the previous studies carried out by Tercia and Teichert (2016) which shows the positive influence of deal proneness on attitude.

Table 6: Hypothesis Testing Results

\begin{tabular}{|l|c|c|c|}
\hline \multicolumn{1}{|c|}{ Hypothesis } & Coefficient & p-value & \multicolumn{1}{|c|}{ Decision } \\
\hline $\mathrm{H}_{1}$ : Deal proneness has a positive effect on attitude & 0,691 & 0,000 & Ha Accepted \\
\hline $\mathrm{H}_{2}$ : Attitude has a positive effect on purchase intention & 0,196 & 0,006 & Ha Accepted \\
\hline $\mathrm{H}_{3}:$ Reciprocity has a positive influence on subjective norms & 0,255 & 0,000 & Ha Accepted \\
\hline $\mathrm{H}_{4}:$ Subjective norms have a positive effect on purchase intention & 0,325 & 0,000 & Ha Accepted \\
\hline $\mathrm{H}_{5}:$ Hypothesis 5 & & & \\
\hline Deal proneness toward purchase intention & 0,753 & 0,000 & Ha Accepted \\
\hline Deal proneness has a positive effect on purchase intention through attitude \\
\hline Deal proneness toward purchase intention & 0,500 & 0,000 & Ha Accepted \\
\hline Deal proneness toward attitude & 0,593 & 0,000 & Ha Accepted \\
\hline Attitude toward purchase intention & 0,223 & 0,060 & Ha Accepted \\
\hline $\mathrm{H}_{6}:$ Hypothesis 6 & 0,725 & 0,003 & Ha Accepted \\
\hline Reciprocity toward purchase intention & 0,193 & 0,003 & Ha Accepted \\
\hline Reciprocity has a positive effect on purchase intentions through subjective norms \\
\hline Reciprocity toward purchase intention & 0,301 & 0,000 & Ha Accepted \\
\hline Reciprocity toward subjective norms & 0,290 & 0,000 & Ha Accepted \\
\hline Subjective norms toward Purchase Intention
\end{tabular}


The second hypothesis tests showed a positive effect of attitude toward purchase intention. This indicated that better consumers' attitude towards the coupons leads to an increase in the purchase intention. It proves that consumers with a positive attitude towards mobile coupons have positive redeeming intentions. This result is in-line with the previous studies carried out by Tercia and Teichert (2016) which show the positive influence of attitude on purchase intention.

The third hypothesis examined the positive effect of reciprocity on subjective norms. This shows that reciprocal actions taken by consumers can be influenced by the positive subjective norms of the people around them. This is in accordance with the research carried out by Tercia and Teichert (2016).

Furthermore, in the fourth hypothesis testing showed the positive influence of subjective norms on purchase intention. It indicates that the better the subjective norms that are received from those closest to the coupon, the higher the consumer's purchase intention. This is in accordance with the Tercia and Teichert's research (2016) which shows the positive influence of subjective norms on purchase intention.

The fifth hypothesis is in accordance with a positive effect on deal proneness on purchase intention through attitude. It shows that deal proneness influences consumer purchase intention towards Starbucks through a positive attitude to the given coupons.

Lastly, the sixth hypothesis which examines the effect of reciprocity on purchase intention through subjective norms showed a positive influence. It shows that the reciprocity by consumers to redeem coupons can be influenced by good subjective norms from the people around them.

\section{CONCLUSION}

In conclusion, when consumers are happy to get a Starbucks (deal proneness) coupon through Line social media, their attitude positively affect their purchasing intention. In addition, consumers' reciprocity to repay the company of its kindness is influenced by the opinions of people around them (subjective norms), which then creates an intention to buy the product (purchase intention). The company's managerial implications for coffee marketing are based on determining the right strategies future to increase the intensity of promotions in the form of coupons. Increasing these benefits tends to encourage consumers to have a positive attitude towards the coupon, thereby, giving rise to purchasing intentions. Marketers also need to express gratitude to consumers that have redeemed their coupons.

This study is limited to consumers that use Line social media and those that are added to Starbucks ' official accounts. In addition, it only used deal proneness, attitude, reciprocity, and subjective norms as variables that affect purchase intention. Therefore, further studies need to be carried out on other food/beverage companies that use Line social media as a tool for promotions in the form of coupons, such as Domino Pizza, Baskin Robbins, Dunkin Donuts, and so forth. Yang and Mattila (2016) also suggested the use of other variables such as hedonic values.

\section{REFERENCES}

Dickinger, A. \& Kleijnen, M. (2008). Coupons going Wireless: Determinants of Consumer Intentions to Re-deem Mobile Coupons. Journal of Interactive Marketing, 22, 23 - 39. 10.1002/dir.20115.

Durianto, D. \& C. Liana. 2004, Analisis Efektifitas Iklan Televisi Softener Soft \&Fresh di Jakarta dan Sekitarnya dengan Menggunakan Consumer Decision Model. Jurnal Ekonomi Perusahaan, 11 (1): 35-55.

Gouldner, H. (1960). Dimensions of Organizational Commitment. Administrative Science Quarterly, 4(4), 468-490. doi:10.2307/2390769

Hair, Black, Babin \& Anderson (2010). Multivariate Data Analysis, Seventh Edition. Pearson Prentice Hall.

Hermawan, A. \& Kristaung (2014). Metodologi Penelitian Bisnis. Cetakan Revisi Kedua. Jakarta: Lembaga Penerbitan Fakultas Ekonomi Universitas Trisakti. 
Kang, H., Hahn, M., Fortin, D., Hyun, Y., \& Eom, Y. (2006). Effects of Perceived Behavioral Control on the Consumer Usage Intention of E-Coupons. Psychology and Marketing, 23(10), 841-864. doi: 10.1002/mar.20136

Kinnear, T. C., and Taylor, J. R. (1995). Riset Pemasaran. Alih Bahasa. Yohanna Lamarto; Jilid II. Erlangga. Jakarta.

Li, Jin, Tangpong, C., Hung, K. T. \& Tony, R. (2013). The Role of Inter-firm Reciprocity Norm and Agent's Conscientiousness in Supply Contract Adjustment Decision. Journal of Business \& Industrial Marketing, Vol. 28 Issue: 8, pp.660-671.

Lin, N \& Lin, B. (2007). The Effect of Brand Image and Product Knowledge on Purchase Intention Moderated by Price Discount. Journal of International Management Studies, p. 121-132.

Montaner, T., Chernatony, L. \& Buil, I. (2011). Consumer Response to Gift Promotions. Journal of Product \& Brand Management, Vol. 20 Issue: 2, pp.101-110.

Mukerjee, H. S., Prasad, U. D. (2017). Definitions of Project Success in Implementation of Customer Relationship Management (CRM) Information Technology (IT) Solutions: Perspectives of Consultants from India. South Asian Journal of Management. Vol. 24 Issue 4, p142-157.

Price, T., Kirkpatrick, M \& Arnold, S. (1988). Directional Selection and the Evolution of Breeding Date in Birds. Science (New York, N.Y.). 240. 798-9. 10.1126/science.3363360.

Ryu, G. \& Feick, L. (2007). A Penny for Your Thoughts: Referral Reward Programs and Referral Likelihood. Journal of Marketing. 71. 84-94. 10.1509/jmkg.71.1.84.

Sekaran, U. and Bougie, R. (2013) Research Methods for Business: A Skill-Building Approach. 6th Edition, Wiley, New York.

Sekaran, Uma. 2010. Metode Penelitian Untuk Bisnis: A Skill Building Approach, $4^{\text {th }}$ Edition, John Willey \& Sons Inc

Sumida, K., Fujimoto, J., \& Sakata, M. (2014). Differentiating Attitudes: Team Loyalty and Attitude towards Spectating Behavior. Sport, Business and Management: An International Journal, Vol. 4 Issue: 2, pp. 109-124.

Tercia, C. Y. \& Teichert, T. (2016). Cultural Context in Word-of-Mouth Activity: How Consumers Respond to Monetary Incentives in WOM. Asia Pacific Journal of Marketing and Logistics, Vol. 28 Issue: 5, pp. 827-840.

Wirtz, J. \& Chew, P. (2002). The Effects of Incentives, Deal Proneness, Satisfaction and Tie Strength on Word-of-Mouth Behavior. International Journal of Service Industry Management, Vol. 13 Issue: 2, pp. 141-162.

X. Ma, L. Chen, Q. Zhu, Y. Liu (2015). Rapid Decoding of Sequence-Specific Nuclease-Induced Heterozygous and Biallelic Mutations by Direct Sequencing of PCR Products Mol. Plant, 10.1016/j.molp.2015.02.012

Yang, W. \& Mattila, A. (2016). Why do we buy Luxury Experiences? Measuring Value Perceptions of Luxury Hospitality Services. International Journal of Contemporary Hospitality Management, 28. 1848-1867. 10.1108/IJCHM-11-2014-0579. 